\title{
Erratum to: Tacks, staples, or suture: method of peritoneal closure in laparoscopic transabdominal preperitoneal inguinal hernia repair effects early quality of life
}

Samuel W. Ross $\cdot$ Bindhu Oommen $\cdot$ Mimi Kim •

Amanda L. Walters • Vedra A. Augenstein •

B. Todd Heniford

Published online: 1 January 2015

(C) Springer Science+Business Media New York 2014

\section{Erratum to: Surg Endosc}

DOI 10.1007/s00464-014-3857-3

The metadata for B. Todd Heniford were incorrect resulting in Given Name: B. and Family Name: Todd Heniford.
This should be corrected to Given Name: B. Todd and Family Name: Heniford.

The online version of the original article can be found under doi:10. 1007/s00464-014-3857-3.

S. W. Ross $(\bowtie) \cdot$ B. Oommen $\cdot$ M. Kim .

A. L. Walters · V. A. Augenstein - B. T. Heniford

Division of Gastrointestinal and Minimally Invasive Surgery,

Department of Surgery, Carolinas Medical Center, 1025

Morehead Medical Drive, Suite 300, Charlotte, NC 28204, USA

e-mail: samuel.ross@ carolinashealthcare.org

B. T. Heniford

e-mail: todd.heniford@carolinashealthcare.org 